\title{
Lebanon's Constitutional Council: \\ Access Blocked to Protect the Consensus System?
}

\section{Nizar Saghieh}

\begin{abstract}
The Lebanese Constitutional Council is vested with the power of assessing the constitutionality of laws and annulling unconstitutional ones. All the other bodies of the State are obliged to apply the laws as long as they have not been declared unconstitutional. From the perspective of strategic litigation on questions of fundamental rights, in view of the limited competences of the Lebanese Constitutional Council to decide on constitutionality of laws, this chapter discusses the historical background and reasons for the current situation of very limited control of the laws' constitutionality. It sheds light on the prevailing political characteristics and perception of the Council's role at his creation and shows the Council' stance by examples of various political, legislative and its' own Council's decisions, arguing for the need not just to reform Lebanon's Constitutional Council, but the perception and role it is driven into by the current political system of consensus.
\end{abstract}

\section{Introduction}

Up to now, the scope of the Lebanese Constitutional Council's work has remained very limited. The ability to challenge the constitutionality of laws before it is restricted to a number of officials and a timeframe of just fifteen days from a law's publication in the Official Gazette. Once this deadline elapses, a new law becomes effective, like all laws that were issued before the Constitutional Council's establishment or went unchallenged, without anyone having the ability to challenge it before any authority, nor any regular court.

We may see this relative closure as an indicator of the level of development of Lebanon's legal system and expect that gradually opening-up is inevitable as the system develops, and as has occurred in several countries, including France (which inspires Lebanon's laws) and many Arab countries, such as Egypt, Jordan, Tunisia, and Morocco. 
However, the Lebanese experience is distinct from the other mentioned experiences, because it is embedded in a system that is based, in principle, on consensus democracy. This distinguishing feature may be explained by the course which the Lebanese system took after the 1975-1990 war, when the performance of the institutions and rule of law declined, and, most importantly, when the ability of non-governmental social forces to exert influence collapsed. Consequently, Lebanon's consensual system - based on observing sectarian quotas - slid from being one being predominantly democratic in character and striving to build shared spaces and institutions and to foster cross-sectarian cooperation among the various social forces (the state), to being one with a charismatic and comprehensive character.

The current consensual system characterized, firstly, by the rallying of the various Lebanese groups (the sects) around zuama (elite political leaders) who monopolize representation and negotiation in their name. Secondly, by the comprehensiveness of the sectarian consensus principle, to the extent that it expands to incorporate the vast majority of public decisions and that consensus is, in practice, valued more highly than all other considerations, including constitutional ones. Usually, this unconditional rallying around the sectarian zuama is reminiscent, to one degree or another, of the ritualistic alignment (occasionally with the zuama themselves) that occurred during war. The best evidence of this transformation is the amnesty law issued in the wake of the war (1991). While this law pardoned political crimes, including major massacres, war crimes, and crimes against humanity, thus retrospectively exempting war-protagonists from legal liability for all crimes committed beforehand, it excluded several crimes, the most important as far as civil society is concerned being crimes committed against political and religious leaders. This indicated that the paramount principle in Lebanon's post-war system is not the human being, as in Europe after the Second World War, but the leader or zaim. This orientation was confirmed in the overall legislative policy after the war, ${ }^{1}$ for which there is no room to detail in this essay.

Because of this transformation, the priorities of public policies changed: While interest in building and fortifying shared institutions and spaces declined, interest in consolidating the zuama's influence and each leader's own ability to divide and attract the populace like magnetic poles increased enormously. This is what the sociopolitical discourse has dubbed

1 Nizar Saghieh, "Beyond Sectarianism: Whom Does the Lebanese State Serve?" The Legal Agenda 32, October 2015, in Arabic under the title "Li-Man/Didd Man Yanbid Qalb al-Madina." 
muhasasa ("quota-sharing"), which, at its core, means shifting from the principle of power-sharing to the principle of sharing resources, posts, and public goods. For example, in Lebanon, judges and officials are chosen not based on their competence, but on their loyalty to a certain zaim. This new system paved the way not just for expanding the scope of the bartering (the "package deal" logic whereby one service is provided in exchange for another, or a person affiliated with a political faction is appointed in a certain position in exchange for the appointment of a person affiliated with another faction in an equivalent position), but also for propagating the logic of negotiation and bargaining, including bargaining over the application of the law and occasionally the Constitution.

Hence, to apply the scientific terms related to consensus systems, it can be said that since 1990, Lebanon has witnessed a shift from the centripetal approach, which is based on directing the social forces towards a common center, towards approaches based on deepening the divide between groups by directing the social forces toward more polarization and sectarian division (the consociational approach). ${ }^{2}$

Consequently, it was natural for the political actors in Lebanon to behave according to the rule that any decision they agree upon takes precedence over any other consideration, including constitutional rules, and therefore with the conviction that virtually the only check on their actions is consensus. Hence, any assessment of the Constitutional Council's role, composition, or power in the Lebanese system would be incomplete if not accompanied by a correct understanding of Lebanon's polarizing consensus system; not just the checks therein, but also the slides it has witnessed.

In this light, how can a judicial institution be given the ability to overturn agreements that the political factions reached, even if unconstitution$\mathrm{al}$, when the general perception of these agreements is that they are more important to the system's stability and continuity than the Constitution itself? Does the existence of a Council of this kind not constitute, if its powers were expanded and it were granted the ability to settle the constitutionality of laws, and hence whether these laws are in effect, a threat to the stability of the comprehensive, polarizing consensus system which the political forces maintain to consider the ideal system for Lebanon?

More gravely, what if the Council annuls part of the law that one faction insisted upon without annulling other parts that another faction

2 Benjamin Reilly, Democracy in Divided Societies. Cambridge University Press, 2001: 20-21. 
insisted upon, potentially giving the upper hand to one side and disturbs the delicate equilibrium between the political forces? Subsequently, what checks would the above change in the understanding of the Lebanese system impose with regard to the composition and powers of this Council and with regard to access for challenging laws? Furthermore, and in light of the above questions, how do we perceive this Council? Do we consider it a public institution outside the system of sharing power and positions, because its fundamental function is to check this system? Or, to the contrary, do we consider it a part and extension of this system, assuming that the system frames its work and that it is governed by considerations identical or at least similar to those that govern the ruling authority?

While these questions can be posed in regard to all the judicial bodies, posing them in regard to the Constitutional Council is more pressing because it is the only institution suited to and charged with assessing the constitutionality of laws and annulling unconstitutional ones. All other bodies are obliged to apply the laws, the laws as long as they have not been declared unconstitutional.

This is what shall be addressed throughout this chapter. Starting off by covering the political authority's perception of this Council's role, the chapter will then covers the Council's interpretation of this role via its rulings and stances.

It must be mentioned that in Lebanon, this Council was established not in the circumstances of a natural development of the laws and institutions, but by the 1991 Constitutional Amendment. This agreement reflected the most important content of the Taif Agreement, i.e. the foundational agreement paving the way out of the 1975-1990 war. Lebanese citizens then had to wait several years for the legal framework for the Council's establishment to be enacted (1993), to be appointed entirely in its first form (1994), and for its internal statue to be adopted (1996). ${ }^{3}$ The Council

3 The Constitutional Council developed its internal statute in accordance with the provisions governing its establishment and deposited it with the General Secretariat of the Council of Ministers on December 19, 1994. The secretariat kept the statute for approximately one year, and Parliament did not adopt it until June 13, 1996. When describing the obstacles that faced the Constitutional Council's establishment, former council member Antoine Khair adds that "At one of the stages of legislation, an article discussing the members' compensation was deleted. This put them in a difficult position as if they addressed this issue, they would appear to be begging for compensation, and if they didn't, they would be subject to working for free after a full-time commitment had been imposed upon them. In reality, I'm sad to say that my colleagues and I, after approximately two years of work, don't know what compensation we might receive. This matter has persisted 
was also suspended at several stages thereafter, most importantly during the period from 2005 to 2008. This period witnessed the repositioning of Lebanon's political forces following the Syrian army's withdrawal from the country and the return of the dominant Christian political leaders to participation in the political arena.

\section{The Constitutional Council established in the image of the consensus system}

The general characteristics and of the Constitutional Council and its perception may be discerned not only from a series of checks that govern its composition, powers, and how it adopts decisions, but also from the taboos that the constitutional legislators included in the Constitution's Preamble, i.e. the reference that governs it. These taboos have flexible meanings, which, if interpreted broadly, could keep the entire legal system subject to the consensus system and its comprehensive and polarizing tendency.

\subsection{Constitutional taboos to immunize the comprehensive consensus system}

It is true that the Taif Agreement included, in its opening section, an explicit declaration of Lebanon's commitment to public liberties and that the constitutional amendment in 1990 introduced into the Constitution's Preamble a commitment to the Universal Declaration of Human Rights and the international conventions that Lebanon has ratified. However, in parallel, this preamble also enshrined constitutional axioms (or perhaps taboos, as I refer to them) aimed at securing the exigencies of the consensus system.

The first, extremely important taboo appeared in Paragraph J, which stipulated that "There shall be no legitimacy for any authority that contradicts the pact of coexistence". As the post-war settlement had reformulated the conditions of power-sharing, this text aimed to reassure the various minorities, particularly the Christians, that the formula, which had previously

for approximately two years from the date of their appointment. We also work without an office, phone, or usher, and we make do with a single staff member to assist us and he is not full-time. We implore some private offices to print and copy the decisions." Antoine Khair, al-Majlis al-Dusturiyy wa-Dawrubu fi al-Raqaba 'ala Dusturiyyat al-Qawanin (The Constitutional Council and Its Role in Monitoring the Constitutionality of Laws): 97 and beyond. 
granted them predominance (the six-Christians-to-five-Muslims formula), became an even split between them and Muslims.

The second and equally important taboo appeared in Paragraph I, which rejects permanent settlement (tawtin) in Lebanon. It aims, in particular, to prevent the naturalization of Palestinian refugees and stateless persons and, in practice, any deepening of the demographic disparity between the sects as a result of such settlement (the overwhelming majority of these refugees are Sunnis).

Via the inclusion of these two taboos in the Constitution's Preamble, these axioms gained constitutional value, which the ruling authority can cite to justify infringing many fundamental rights or adopting many discriminatory measures that might be considered unconstitutional in other constitutional systems.

This issue was exacerbated by the flexible nature of the phrases "permanent settlement" and "the pact of coexistence", which allowed and continues to allow for their effects to be expanded - and therefore the danger they pose to ensuring fundamental rights without discrimination. This shall be explained below by examining some of the Constitutional Council's works related to these two concepts.

\subsection{The Constitutional Council's composition and the means of appointing its members}

Another check that can be discerned from the law establishing the Constitutional Council is the means of appointing its members. Half of the ten members are appointed by Parliament and half by the Council of Ministers. Their appointment in Parliament requires that they obtain an absolute majority in the first round and a plurality in the second round, and their appointment in the Council of Ministers requires that they obtain a two-thirds majority. This means that the Constitutional Council's members appointed by the Council of Ministers are appointed in accordance with the principle of quota-sharing by the main forces participating in government. Hence, these forces (should they be able to gather a "disrupting third" of the ministers) have the right to veto if they are unsatisfied with the appointments that occur in Parliament or do not agree to the candidates in the Council of Ministers.

Here, attention must be draw to three matters: 
- Firstly, the Constitution did not stipulate any condition regarding the sectarian affiliation of the Constitutional Council's members. Article 95 explicitly excluded the judicial bodies from the sectarian representation rule. The law establishing the Constitutional Council, issued in 1993, and its amendments in 2006 and 2008 went in the same vein. Nevertheless, the customs adopted since the appointment of the Council's first form involved the imposition of an equal split between Christians and Muslims. Additionally, the principle of a split according to denomination prevailed, meaning that the Council came to be composed on the basis of two Maronites, two Orthodox, one Catholic, two Sunnis, two Shia, and one Druze. The sectarianization was officially consecrated in the 2017-2019 period via the emphasis on the aforementioned sectarian formula in the mandating reasons of two laws issued in 2018 and 2019 to extend the deadline for submitting candidatures for positions in the Council. These reasons explicitly stated that none of those who had submitted their candidatures in 2015 before the legal deadline fulfilled the condition of membership in the Roman Catholic sect. It also stated that sects, customarily represented by two Council members, were only represented by two candidates, which "makes election in Parliament and appointment in the Council of Minister pointless". Hence, the mandating reasons consisted in the need to reopen the door for candidatures to guarantee the representation of certain sects or provide a choice between the candidates from others.

This custom was exacerbated by the fact that the principle of consensus on the candidates has not consisted in choosing consensus candidates in the sense that they are accepted by all the various political actors. Rather, in most instances, particularly in the latest appointments in 2019, it resulted in enabling every political force preponderant within its sect to name the member belonging to this sect. Subsequently, the sectarian representation of the Council's members transformed into a tool to ensure quota-sharing within the Council between the participants in government. This ensures that these members are subject to considerations that are identical or at least similar to the consensus-related considerations that drive the ruling authority. In 2019, the quotasharing reached a high degree of crudity, particularly when one political faction-namely the Lebanese Forces, the second-largest Christian force in Parliament and the Council of Ministers-accused the others of violating the quota-sharing conditions and consequently depriving it of its agreed-upon share. That share went, via the appointments by the Council of Ministers on August 22, 2019, to the strongest Christian party. 
- Secondly, the rules of appointment have been amended over the past three decades. Initially, appointment occurred without prior submission of candidature (the 1993 law). Then it occurred following candidature submission and an interview conducted by Parliament's Administration and Justice Committee (the 2006 amendment law). Later, it occurred based on candidature submission but without an interview (the 2008 amendment law). This resulted in customs whereby the candidates conduct visits to the political forces, particularly those that appoint the members from these candidates' sects, in order to convince those forces to appoint them.

- The third matter is the 2012 legislative intervention (the law of October $28,2012)$ to abolish a rule stipulated in the 2008 Amendment whereby half the members of the Council's first form under that law would be selected by lot and replaced three years after swearing the legal oath. Hence, all members of the Constitutional Council remained in office, which allowed the ruling authority to appoint an entirely new membership in 2019, four years after the term of all the members had expired.

In practice, this amendment reinforces the quota-sharing principle and the package-deal principle in appointments, as otherwise it would be unpredictable who would have to leave the Council due to the means of expulsion by lot. More importantly, the abolishment of the rule of 2008 tends to exclude the possibility that the Constitutional Council would include members appointed by forces that had lost their positions in government. By abolishing rotation, all the members are appointed at one time by the same ruling forces, which has occurred in 2019. The abolishment of the lot constituted another example of the Lebanese system's ability to circumvent best practices in appointing the Council Members adopted in many countries in order to establish the practices that serve its interests. The remarkable aspect of this law is not just its content but also its mandating reasons, the point of which was to prevent the disruption of the Council that could occur if members were expelled by lot while the ruling class could not agree on their replacements. The mandating reasons for the bill explicitly mention that Lebanon's democracy is weak and the obligation to elect a new membership for the Constitutional Council constantly went unfulfilled.

Consequently, the Constitutional Council has appeared, in its composition, to be more of an extension of the political system than a check to confirm that this system respects the Constitution. The best example 
of this, and of the ties between the political zuama and the Council's members, is the challenge to the law extending Parliament's term in 2013. The said challenge failed because of the Constitutional Council's inability to adopt a decision on it within the legal timeframe as its quorum was disrupted by the absence of three members. In an issue on June 11, 2013, Lebanese daily Al-Akbbar interpreted their absence with the statement that "Parliament Speaker Nabih Berri [the prominent Shia zaim] and MP Walid Jumblatt [the prominent Druze zaim] are in agreement to disrupt the Constitutional Council's quorum by commanding the two Shia members and the Druze member not to attend the sessions". Assafir, another daily, chose to give its editorial published the same day a more expressive headline: "The Constitutional [Council] Challenges Itself: Command is for the Sects' Kings".

While from a legal perspective it is possible to view this action as merely a denial to administer justice for which the absent judges are responsible and to consider them as having resigned from their positions, things appear completely different when read via the lens of the political situation: Considering them resigned would, in practice, reduce the Council's members to seven, which would prevent it from convening at all. This would mean to totally suspend it, especially as the forces supporting those judges could, in principle, prevent the appointment of their replacements by Parliament or the Council of Ministers, which in practice only occurs via consensus.

From this angle, the disrupted quorum incident can be read in a totally different manner, namely as adapting the Constitutional Council system to the exigencies of the prevailing system. The Council's inability to examine a challenge because of the intentional absence of three members entails, in practice, not just propagating and legitimizing the culture of political interference in the judiciary. Before else, it is opening the door for the spread of the culture of consensualism within the judiciary (or at least, as far as we are concerned here, the Constitutional Council) such that there can be no judicial decision or resolution of disputes in the event of the so-called "disrupting quarter". In this sense, the action of those judges is an indication of the development of a different understanding of the principles of judicial work and the judicial function, an understanding that forges this function in the crucible of the Lebanese system and exploits it so that it serves that system, rather than checks or develops it. 


\subsection{The Constitutional Council's powers}

The Constitutional Council's powers have also been influenced by the polarizing consensus system's considerations as the possibility of appealing to the Council, which threatens the orientations or laws on which the ruling political powers might reach a consensus, has been constricted. This can be discerned from two angles:

Firstly, the ability to challenge the constitutionality of laws was restricted to the President of the Republic, the Prime Minister, Parliament Speaker, and ten MPs, as well as the heads of the legally recognized sects when it comes to matters of personal status, freedom of belief, the practice of religious rites, and freedom of religious education (Article 19 of the Constitution). The law establishing the Constitutional Council (1993) also constricted this ability by limiting it to laws issued recently and requiring that the challenge be submitted within fifteen days of their publication. Besides the fact that this immunized all old laws, it also ensured that new laws are immunized if the forces wanting to challenge them fail to obtain the signature of the President, the Prime Minister, or the Parliament Speaker or the signatures of ten MPs. One of the most important and dangerous laws that was passed recently and that the MPs did not succeed in providing the number required to challenge is the law settling building violations committed between 1971 and 2018, i.e. over approximately half a century. This settlement severely impacts the environment and the aesthetics of the cities. It also rewarded the parties that violated the construction laws, which, via this law, overcame the legal challenges still pending against them at the time of its issuance.

This immunization peaked with the prohibition of all other judicial bodies from examining the constitutionality of laws, contrary to the situation before the Constitutional Council's establishment (Article 18 of the 1993 law).

Accordingly, in some instances Parliament has had no qualms about explicitly declaring that it is in the process of adopting an unconstitutional law because of its confidence that the number required to challenge it is not present. This occurred, in particular, with the adoption of the law extending the effective period of the provisional twelfth principle (which allows the government, in the absence of a budget, to continue spending in accordance with the previous budget) in 2019.4

4 “al-Nuwwab Yastajibuna li-Da’wat Wazir al-Maliyya bi-Mukhalafat al-Dustur: Lubnan tahta Hukm Qa'idat al-Ithnay “Ashariyya Mujaddadan” (“The MPs Respond to 
The second angle consists in an issue settled with the constitutional amendment in 1990, namely stripping the Constitutional Council of the power to issue opinions interpreting the Constitution separate from any dispute (a power stipulated in the Taif Agreement) on the pretext that Parliament alone many interpret the Constitution. This issue witnessed extensive debates within Parliament and clearly reflected Parliament's apprehension toward interpretations that could preemptively restrict its ability to legislate and subsequently limit the scope of potential bargaining. ${ }^{5}$ The desire to strip the Constitutional Council of the power to interpret the Constitution has reached surreal levels whereby Parliament Speaker Nabih Berri went so far as to deny the Council's power to interpret the Constitution even when examining one of the challenges filed to a law's constitutionality. ${ }^{6}$

\section{The Constitutional Council's perceptions of its role under the consensus} system

How have the Constitutional Council's members interacted with this reality? Have they succeeded in distancing themselves from the political system? Have they succeeded in curbing abuse of authority or at least formulating principles or guidelines that could fortify rights gains or consolidate them in future?

Answering this question definitively is difficult for several reasons, including the large discrepancy between the Council's three forms, whose members were appointed in different political circumstances. The first two forms were appointed under the so-called Syrian tutelage and in the absence of the most popular Christian leaders, whereas the third form was appointed after the decline in Syrian influence and the Christian leaders' return to participation in political life.

Another, equally important factor preventing any general theory is the small number of law challenges brought before the Constitutional Coun-

the Call by the Minister of Finance to Violate the Constitution: Lebanon Under the Rule of the 12 ${ }^{\text {th }}$ Once Again”), The Legal Agenda website, March 25, 2019.

5 Minutes of Parliament, $17^{\text {th }}$ legislative cycle, first exceptional convention, third session, held on August 21, 1990.

6 Wissam Lahham, "Lebanese Ruling: The Constitution is Sovereign, not Parliament." The Legal Agenda website, September 28, 2017, in Arabic under the title "Siyadat al-Dustur La Siyadat Majlis al-Nuwwab: Ta'liq 'ala Qarar al-Dusturiyy bi-Sha'n Ibtal al-Ziyadat al-Daribiyya”. 
cil. ${ }^{7}$ Hence, I will merely mention some stances that can be seen as indicative, and comment on them without claiming any general conclusions in this regard. Thus, here the Council's orientations shall be addressed with regard to situations, where laws have been challenged before it that could be considered sensitive; sensitive, either because of their connection to one of the aforementioned constitutional taboos (the prohibition of permanent settlement and the pact of coexistence) or because they were adopted by consensus even though they obviously contradict the Constitution.

\subsection{The taboos before the Constitutional Council}

For understanding what has developed as taboos before the Constitutional Council, two laws that the Constitutional Council addressed should be mentioned in particular:

- The first is the law on property ownership by foreigners issued in 2001. This law included an explicit clause stating that "No right in rem of any kind may be owned by any person who does not have the nationality of a recognized state, nor by any person if the ownership conflicts with the Constitution's provisions concerning permanent settlement".

This text is understood as prohibiting stateless persons and, implicitly, Palestinian refugees from owning real estate in Lebanon, whether obtained via sale, gift, or inheritance.

A challenge was filed against this law before the Constitutional Council for discrimination, citing the Constitution and several international conventions. In 2001, the Council dismissed the challenge, arguing that "The constitutional authorities have sovereign rights reserved on Lebanese territory, so they may prohibit ownership if it contradicts their supreme policy of rejecting permanent settlement”. These grounds reflect an expansion by the Council in applying the taboo against settlement from two angles. Firstly, they expand the taboo's definition and scope: the "prohibition on permanent settlement" enshrined in the Constitution's Preamble encompasses not only granting Palestinian refugees Lebanese nationality but also granting them any civil rights that could facilitate or pave the way for obtaining nationality or enhance its legitimacy (as is the case with the right to ownership)

7 Twenty-five decisions between 1994 and 2005 and ten decisions between 2008 and 2014. 
with no exceptions, not even for refugees who have strong ties to Lebanon, such as those married or born to Lebanese women.

Secondly, and perhaps more gravely, it put the prohibition on permanent settlement within the category of "supreme policy". This means the adoption of a certain hierarchy among the constitutional provisions and ultimately giving this principle precedence over the whole human rights system enshrined in the same preamble.

- The second law in this area is the renaturalization law, which aimed to ease the administrative procedures enabling the descendants of Lebanese emigrants to recover Lebanese nationality. The law excluded the descendants of female emigrants, thereby repeating the provisions of the Lebanese nationality law, which still deprives Lebanese women of the ability to bestow their nationality onto their children. It also excluded Lebanese who had chosen the nationality of a country that separated from the Ottoman Empire, the goal being to avoid renaturalization requests coming from the surrounding countries, particularly Syria and Palestine. This law, with what it permits and withholds, clearly touches another taboo, namely the pact of coexistence, from two angles. Firstly, when the law was developed, the Christian political forces assessed that facilitating the renaturalization of emigrants' descendants would increase Christians' numbers and reduce the demographic disparity between them and Muslims. Secondly, they succeeded in ruling out abolition of the gender discrimination in granting citizenship after it became evident that most of the children of Lebanese women who could benefit from the discrimination's abolishment are Muslims. ${ }^{8}$ While the MPs of the Democratic Meeting bloc filed a challenge against this law on the basis of the discrimination against the descendants of people who chose the nationality of a former Ottoman Empire state, "The Legal Agenda", together with the "My Nationality is a Right for Me" and "My Family campaign", promptly composed a memorandum drawing the Constitutional Council's attention to a graver form of discrimination that the challenger had disregarded,

8 Saada Allaw, "Siyada Jadida bi-Ism al-Maslaha al-'Ulya: 'al-Dawla al-Dhukuriyya' Tadfan Haqq al-Mar'a al-Lubnaniyya bi-Manh Jinsiyyatiha li-Awladiha Niha'iyyan” ("New Sovereignty in the Name of Paramount Interest: 'the Patriarchal State' Buries the Lebanese Woman's Right to Bestow Her Nationality on her Children For Good”), The Legal Agenda website, January 15, 2013. 
namely the gender discrimination. ${ }^{9}$ On January 7, 2016, the Constitutional Council dismissed the challenge on the basis that "The law did not discriminate whatsoever on the basis of race, religion, or affiliation but instead enshrined an inclusive general principle from which Lebanese benefit", totally neglecting to examine the gender discrimination. The Council thereby seemed, contrary to its previous jurisprudence, to be voluntarily limiting its comprehensive power to exercise oversight over all the law's clauses and not just those related to the challenge's arguments, all for the sake of preserving this law despite its blatant gender discrimination because of its connection to coexistence considerations. ${ }^{10}$

Only the Council's Vice President, Judge Tareq Ziade, differentiated himself in this case. He recorded a dissenting opinion deeming that the law should be annulled because it totally contradicts the principle of gender equality, ${ }^{11}$ adding that "No new law may contravene the Constitution" 12 and "The council, while examining a petition, cannot ignore a text that contravenes the Constitution".

\subsection{Consensus laws that obviously contravene the Constitution}

In this regard, the most important laws that have been challenged include the 2014 law to extend Parliament's term and the 2018 State budget law. Note that the Constitutional Council was unable to examine the challenge

9 Memorandum by The Legal Agenda and the My Nationality is a Right for Me and My Family campaign challenging the renaturalization law, The Legal Agenda website, December 22, 2015.

10 "al-Mufakkira al-Qanuniyya Tanshur al-Qarar fi Qadiyyat al-Ta'n bi-Qanun Isti'adat al-Jinsiyya: al-Majlis al-Dusturiyy Yudi' Fursa Tarikhiyya li-Insaf al-Nisa”" ("The Legal Agenda Publishes the Decision in the Case of the Challenge to the Renaturalization Law: the Constitutional Council Wastes a Historical Opportunity to Do Women Justice"), The Legal Agenda website, January 8, 2016.

11 "Mukhalafat Ziyada 'ala Qarar al-Dusturiyy 1/2016: Rafd li-Imtina' al-Majlis 'an Ihqaq al-Haqq" ("Ziade's Dissent to Constitutional [Council] Decision 1/2016: A Rejection of the Council's Abstention from Doing Justice”), The Legal Agenda website, January 11, 2016.

12 See also Mirai Najm Shukrallah and Paul Morcos, al-Majlis al-Dusturiyy al-Lubnaniyy fi al-Qanun wa-l-Ijtihad (The Lebanese Constitutional Council in Law and Jurisprudence), the UNDP's Lebanese Elections Assistance Project (LEAP) in cooperation with the Constitutional Council, 2014: 106. 
filed against the law to extend Parliament's term for the first time in 2013 because of the absence of three of its members, as previously explained.

The decisions in these two cases reveal that the Council merely performed a guiding, advisory role. This role consisted of recalling the Constitution's provisions and warning the political authority of the seriousness of infringing them without going so far as to annul either law.

In the first case, the Council dismissed the challenge on November 28,2014 , on grounds that appeared contradictory. The decision not only emphasized all the constitutional principles that prohibit extending Parliament's term in this manner but also explicitly declared multiple times that extending it for two years and seven months conflicts with the Constitution. Thus, the decision declared that "the periodicity of elections is a constitutional principle that may absolutely not be infringed", that rendering the holding of elections contingent on agreement on a new election law is an act that contravenes the Constitution, and that while the exceptional circumstances might justify postponing the elections for a limited time, "they do not justify extending Parliament's term for two years and seven months". Yet all this did not prevent the Council from ultimately dismissing the challenge "to prevent further occurrence of a vacuum in the constitutional institutions". Some deemed that the Council had put a constitutional goal (preventing a vacuum) before annulling the constitutional violation without any attempt to weigh the two matters against each other in light of the principle of proportionality.

Thus, by refusing to annul the law, the Constitutional Council complied with consensus occurring in contravention of the Constitution and allowed Parliament in future to practice the same blackmail by forcing a choice between an extension and a vacuum. This would, in fact, later happen: Parliament extended its own term for the third time in 2017 in the body of the new parliamentary elections law such that its total extended term reached approximately nine years.

The Constitutional Council's stance in the second case was no clearer. To understand the significance of this decision, we must recall that Lebanon witnessed an unusual situation from 2005 to 2017: it was one of the few countries wherein governance continues without annual budget laws and without closure of accounts laws (i.e. laws that certify the outcome of the annual budget's implementation) in clear violation of the Constitution. Article 87 of the Constitution details the procedures that the enactment of a budget law for the following year should follow, including prior certification of the previous year's accounts-i.e. the so-called "closure of accounts" law. This is an important measure as it provides an idea about the budget's credibility and transparency and the correspondence between 
the estimated budget and the budget's implementation. In 2017, it was decided to enact a budget for that year (albeit late) but without a closure of accounts. In 2018, the same scenario reoccurred: the government was again unable to certify the accounts of the past years.

A challenge was filed against the 2018 budget law, and on May 14, 2018, the Constitutional Council issued a decision to annul seven of its articles for reasons that there is no room to dwell on here, the most important being that they were off-topic (cavaliers budgetaires). On the other hand, it rejected the argument concerning the unconstitutionality of adopting a budget in isolation from a closure of accounts law for the previous year. It did so to avert an outcome in which Lebanon has no budget law. Here, the Council's grounds closely resembled its grounds in the decision to dismiss the challenge to the law extending Parliament's term.

Although the Council emphasized that adopting the budget without a closure of accounts law for the previous year is a breach of the Constitution and the separation of powers principle and an encroachment on the powers of the judiciary and Parliament and their role in overseeing how the state budget is implemented, it opted not to annul the law on account of this breach because of the country's need for a budget. Hence, the Council seemed to be saying that having a lame state budget lacking credibility is better than not having a state budget at all. To reach this conclusion, the Council adopted unfamiliar reasoning rather than deeming a closure of accounts law a precondition for the validity and credibility of the State budget law, as Article 87 requires, it gave the duty to adopt a state budget exceptional constitutional value higher than the value of adopting a closure of accounts law, for not adopting a budget has negative consequences for the state and leads to chaos in public finance. The Council thereby deduced that the more important law cannot be abolished because of the absence of a less important law. The closure of accounts "was established ... for the sake of the state budget; the budget was not established for the sake of the closure of accounts".

Once again, the first criticism of this stance came from the Vice President of the Constitutional Council Tareq Ziade, who composed a dissenting opinion concluding that the law should be annulled because of the absence of the closure of accounts law. One of the most prominent parts of this dissent stated that the principle of public interest is, according to constitutional jurisprudence, a secondary principle that acts as a supplement in the absence of a text. In other words, it should not be taken into account when there is an explicit, clear, definitive, and binding text (namely Article 87 of the Constitution). Ziade also criticized the Constitutional Council's use of the concept of an "abnormal situation" to describe the 
absence of a state budget. After noting that this concept is vague and has not appeared in constitutional science and jurisprudence, he opined that it "is another term for exceptional circumstances that should not be taken into account when there is a text and that are not present to begin with".

\section{Conclusion}

As has been underpinned by the arguments laid out in this chapter, the Constitutional Council of Lebanon up to now did not manage to take a role in the post-1991 developments, by which it would emerge from rather than succumb to the problematics of the consensual system. Merely attributing additional competences and power to it would not solve the problem. To disrupt the constant threat of a culture of consensualism spreading within the judiciary and to the Constitutional Council, with long-lasting consequences, one would have to reconsider the appointment mechanisms, the axioms or taboos and with them the scope of the Council's jurisdiction and accessibility. This may only be achieved by a change of understanding of the principles of judicial work and the judicial function, away from the one that forges this function in the crucible of the Lebanese system and exploits it so that it serves the current system, but towards an understanding that develops it. 
